\title{
Artyfechinostomum malayanum: Metacercariae Encysted in Pila sp. Snails Purchased from Phnom Penh, Cambodia
}

\author{
Woon-Mok Sohn 1,*, Tai-Soon Yong², Keeseon S. Eom³, Muth Sinuon ${ }^{4}$, Hoo-Gn Jeoung ${ }^{5}$, Jong-Yil Chai5,6,* \\ ${ }^{1}$ Department of Parasitology and Tropical Medicine, and Institute of Health Sciences, Gyeongsang National University School of Medicine, Jinju \\ 52727, Korea; 'Department of Environmental Medical Biology and Institute of Tropical Medicine, Yonsei University College of Medicine, Seoul \\ 03722, Korea; ${ }^{3}$ Department of Parasitology, Medical Research Institute and Parasite Resource Bank, School of Medicine, Chungbuk National \\ University, Cheongju 28644, Korea; ${ }^{4}$ Center for National Malaria Control, Phnom Penh, Cambodia; 5 Institute of Parasitic Diseases, Korea Association \\ of Health Promotion, Seoul 07653, Korea; ${ }^{6}$ Department of Parasitology and Tropical Medicine, Seoul National University College of Medicine, Seoul
} 03080, Korea

\begin{abstract}
The metacercariae of Artyfechinostomum malayanum (Leiper, 1911) Mendheim, 1943 were discovered in Pila sp. snails purchased from a market in Phnom Penh, Cambodia. They were isolated from the snails using the artificial digestion technique and were orally fed to 2 hamsters, 1 rat, and 2 mice to obtain the adult flukes. The metacercariae were round, $145-165 \mu \mathrm{m}$ in diameter, having a cyst wall of 6-10 $\mu \mathrm{m}$ in thickness, a head collar and collar spines, and characteristic features of excretory granules. Adult flukes were recovered in the small intestines of the animals at days 14 and 32 post infection and were morphologically observed using a light microscope and a scanning electron microscope. They were plump or elongated, ventrally curved, $6.0-8.1 \times 1.6-2.0 \mathrm{~mm}$ in size, and characterized by the head collar bearing 43 collar spines, including 5 end group ones on each side, a long cirrus sac extending beyond the posterior margin of the ventral sucker, a submedian ovary, and 2 deeply lobed testes. Eggs in uteri were operculate, ovoid to ellipsoid, and 120$135 \times 68-75 \mu \mathrm{m}$ in size. In scanning electron microscopy, the head collar was prominent with collar spines looking like horns. Scale-like tegumental spines were densely distributed on the ventral surface between the head collar and ventral sucker. Sensory papillae were distributed mainly on the tegument around suckers. By this study, it has been first confirmed that the life cycle of $A$. malayanum exists in Cambodia.
\end{abstract}

Key words: Artyfechinostomum malayanum, echinostome, metacercaria, adult fluke, Pila sp. snail, scanning electron microscopy, Cambodia

Artyfechinostomum malayanum (Leiper, 1911) (Digenea: Echinostomatidae) was originally described from the intestine of humans (Tamil people) in Singapore and Kuala Lumpur, Malaysia under the name Echinostoma malayanum [1]. In 1957, Bisseru [2] suggested to move this species to Artyfechinostomum Lane, 1915 because of the characteristic features of the cirrus sac extending beyond the posterior level of the ventral sucker and deeply lobed testes. Further human infections were found in Malaysia [3,4], Indonesia [3], the Philippines [5,6], India [7], Thailand [8], and Lao PDR [9]. Its first intermediate host is freshwater snails, Indoplanorbis exustus and Gyraulus convexiusculus [10]. The metacercariae of A. malayanum were found to encyst in snail species, Pila scutata, Lymnaea (Bullastra) cumingiana, and Digoniostoma pulchella [10,11].

\footnotetext{
- Received 1 May 2017, revised 6 May 2017, accepted 1 June 2017.

*Corresponding authors (cjy@snu.ac.kr; wmsohn@gnu.ac.kr)

(c) 2017, Korean Society for Parasitology and Tropical Medicine

This is an Open Access article distributed under the terms of the Creative Commons Attribution Non-Commercial License (http://creativecommons.org/licenses/by-nc/4.0) which permits unrestricted non-commercial use, distribution, and reproduction in any medium, provided the original work is properly cited.
}

In Cambodia, reports have been published regarding the distribution of a few species of echinostomes but never on $A$. malayanum. Human Echinostoma revolutum infection (the species name in this occasion needs to be further evaluated by molecular methods) was discovered in Pursat Province, with the egg prevalence of $11.9 \%$ among 471 schoolchildren examined [12]. Soon after this, human cases infected with Echinostoma ilocanum were also discovered in Oddar Meanchey Province, with $1.0 \%$ egg positive rate among 1,287 villagers [13]. In addition, in Takeo Province, where Opisthorchis viverrini was found endemic, 52 cases (2.9\%) of 1,799 villagers examined were positive for echinostome eggs (species undetermined) in fecal examinations [14]. From animals, only 1 available literature reported infection of Asian house shrews with Echinostomatidae flukes (species undetermined) [15]. However, no studies have been performed regarding the life cycle and intermediate hosts of echinostomes in Cambodia. In this study, we discovered the metacercariae of A. malayanum in Pila sp. snails purchased from Phnom Penh, Cambodia and identified the species morphologically by obtaining adult flukes (Fig. 1A) 
and eggs (Fig. 1B) after experimental infection to animals.

We purchased Pila sp. snails (Fig. 1C) in a local market of Phnom Penh, Cambodia in April 2008. They were transferred to our laboratory on ice, and digested with pepsin- $\mathrm{HCl}$ solution after crushing their shells with a mortar with a pestle for 2 hr. Metacercariae were collected from the digested materials under a stereomicroscope. Collected metacercariae were morphologically observed and measured using a light microscope with a micrometer. They were then orally fed to 2 hamsters, 1 rat, and 2 mice. Adult flukes were recovered in the small intestines of these animals 2 weeks after the infection. Twenty adults recovered from them were fixed with 10\% neutral buffered formalin under a cover slip pressure, stained with Semichon's acetocarmine, and observed under a light microscope.

To observe the surface ultrastructure, some of them were washed several times with $0.2 \mathrm{M}$ cacodylate buffer ( $\mathrm{pH} 7.2)$ and fixed with $2.5 \%$ glutaraldehyde at $4^{\circ} \mathrm{C}$. After washing 3 times with the buffer, they were dehydrated through a graded series of alcohol $(50 \%, 70 \%, 80 \%, 90 \%, 95 \%$, and absolute alcohol), dried in a critical point dryer, coated (JFC-1100E ion sputtering device, Tokyo, Japan) with gold, and observed using a scanning electron microscope (Philips XL-30S, Eindhoven, the Netherlands) at an accelerating voltage of $20 \mathrm{kV}$.

The overall infection rate of Pila snails with A. malayanum metacercariae was around 70\% (210/300). More than 350 metacercariae were detected in about 300 snails. The metacercariae were round, 145-165 (av. 154) $\mu \mathrm{m}$ in diameter with a cyst wall of 6-10 $\mu \mathrm{m}$ thickness, and equipped with collar spines on the head collar and excretory granules in 2 descending canals of the main excretory tube (Fig. 1D). A total of 65 adult flukes were recovered from 1 hamster, 1 rat, and 2 mice, with the average worm recovery rate of $59.1 \%$ at day $14-32$ post infection. The measurements are given in $\mathrm{mm}$ (eggs are shown in $\mu \mathrm{m}$ ) unless otherwise stated.

The adult flukes were elongated, ventrally curved, and 6.08.1 × 1.6-2.0 mm in size. Head collar (0.13-0.16 ×0.32-0.37 $\mathrm{mm}$ in size) distinct, bearing 43 collar spines with 5 end group spines on each side (Fig. 2). Oral sucker almost round (0.16-
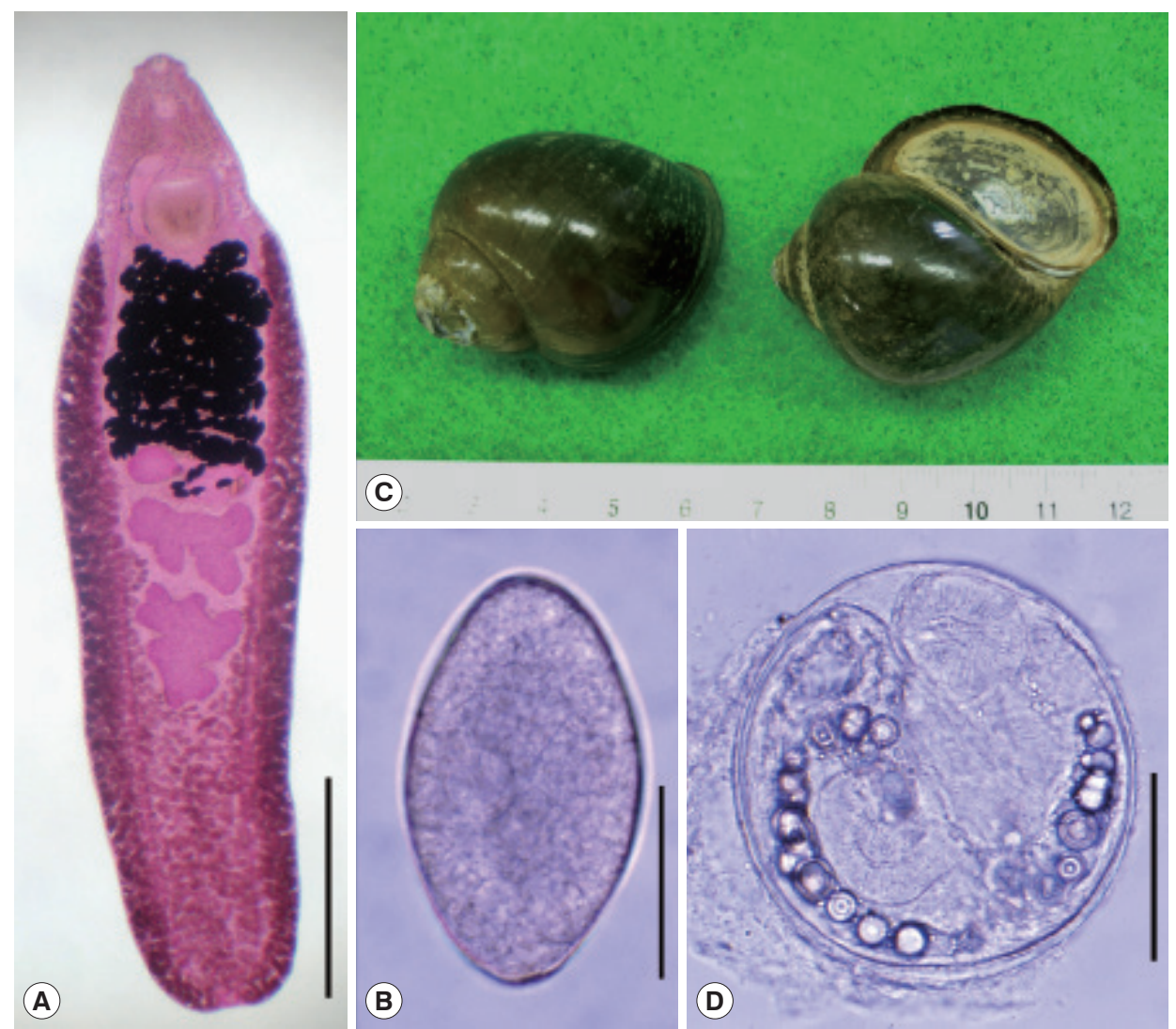

Fig. 1. An adult (A), egg (B), snail host, Pila sp. (C), and metacercaria (D) of Artyfechinostomum malayanum obtained in Cambodia. The snail host was purchased in a local market of Phnom Penh. Adult flukes were recovered in a hamster, a rat, and 2 mice after experimental infection with the metacercariae. Scale bars $=1.7 \mathrm{~mm}(\mathrm{~A}), 60 \mu \mathrm{m}$ (B), $75 \mu \mathrm{m}$ (D). 
$0.19 \times 0.17-0.19 \mathrm{~mm}$ in size) and subterminal. Prepharynx (0.14-0.18 mm in length) short, pharynx $(0.16-0.18 \times 0.14-0.17$

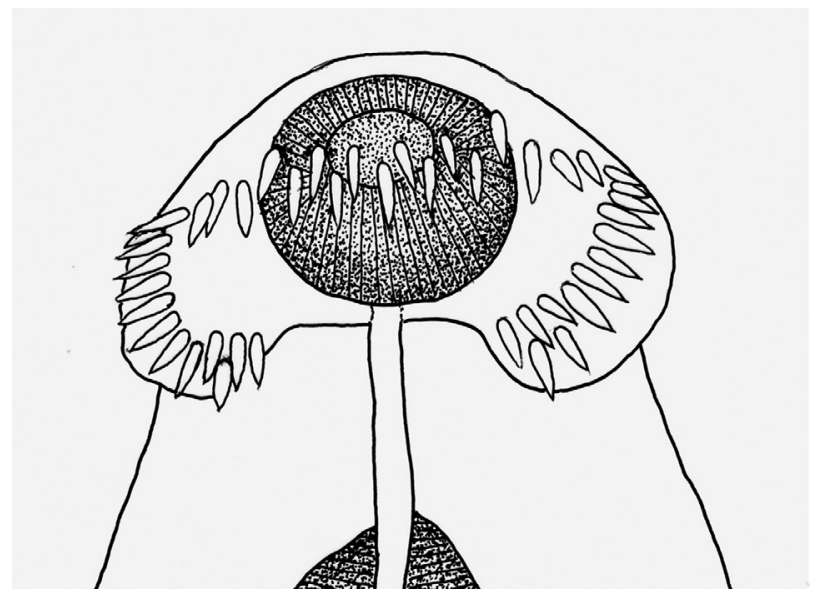

Fig. 2. Drawing of the head collar with collar spines in an adult fluke. The total number of collar spines was 45 , and the number of end group spines on each side was 5 . Scale bar $=40 \mu \mathrm{m}$. $\mathrm{mm}$ in size) well developed. Esophagus somewhat long (0.18$0.23 \mathrm{~mm}$ in length). Cirrus sac well developed, containing a long saccular seminal vesicle $(0.38-0.80 \times 0.17-0.28 \mathrm{~mm}$ in size). Ventral sucker very large $(0.49-0.60 \times 0.50-0.62 \mathrm{~mm}$ in size). Ovary elliptical $(0.27-0.48 \times 0.30-0.45 \mathrm{~mm}$ in size $)$, dextral, and pre-equatorial. Two testes $(0.47-0.95 \times 0.87-1.20 \mathrm{~mm}$ and $0.65-1.35 \times 0.85-1.15 \mathrm{~mm}$ in size) tandem and deeply lobed. Eggs operculate, elliptical, and 120-135×68-75 $\mu \mathrm{m}$ in size (Fig. 2).

In scanning electron microscopic observations, the head collar was prominent around the oral sucker, bearing total $43 \mathrm{col}$ lar spines which looked like horns in younger stags (Fig. 3A, $B)$. The scale-like tegumental spines were densely distributed on the ventral surface between the head collar and ventral sucker, with their densities decreased posteriorly. Sensory papillae were distributed mainly on the tegument around suckers (Fig. 3C).

There have long been debates and confusion in the taxono-
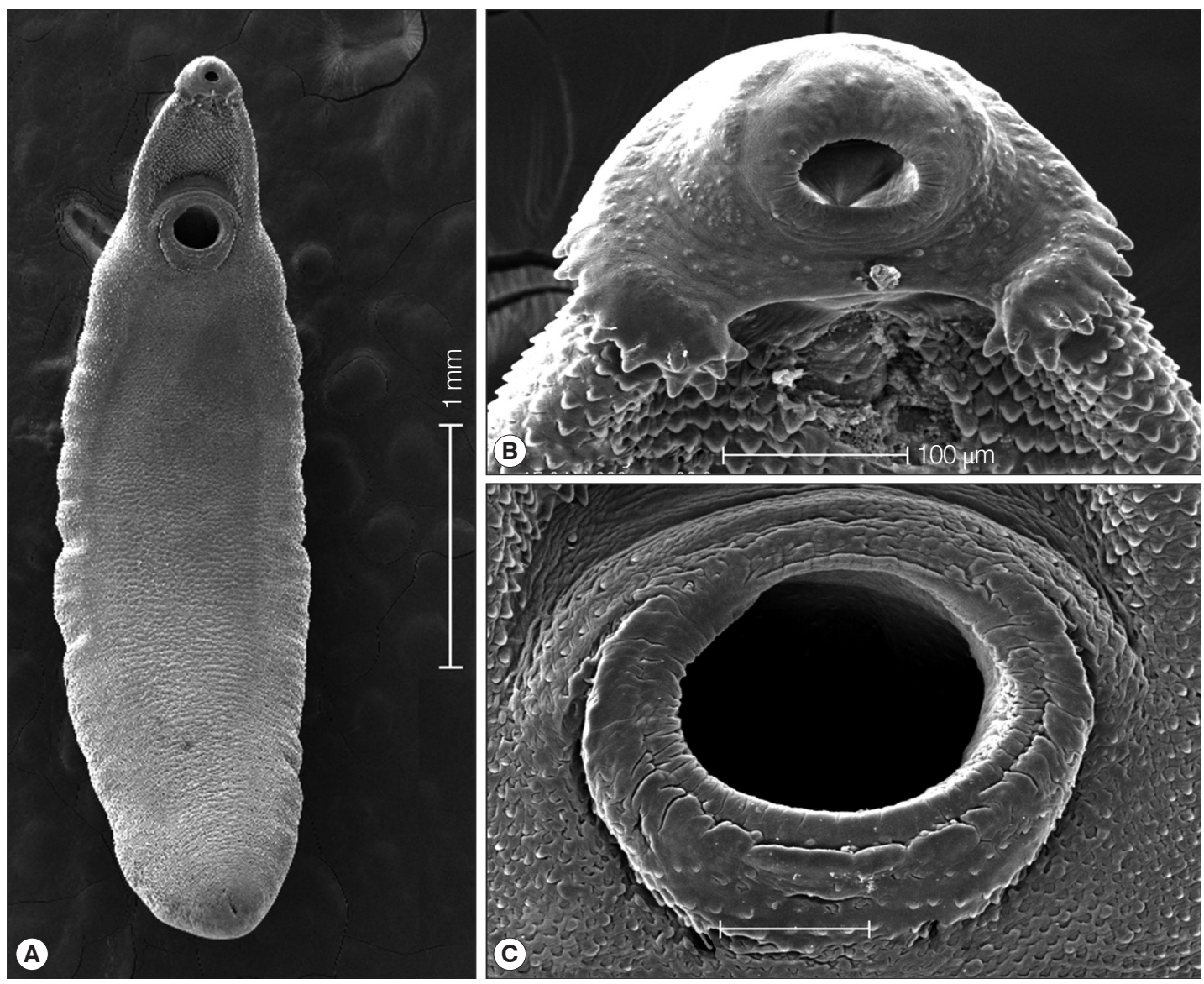

Fig. 3. SEM findings of the adult $A$. malayanum. A whole worm view (A), a close-up of the head collar with collar spines (B), and sensory papillae on the lip of the ventral sucker $(\mathrm{C})$. 
my of A. malayanum. The first human infection with this fluke was reported in Malaysia under the name Echinostoma malayanum by Leiper in 1911 [1]. The name of this fluke was changed into Euparyphium malayanum by Odhner in 1913 [16], but in 1957 Bisseru [2] proposed to transfer this to a different genus Artyfechinostomum and called A. malayanum. However, Lie [17] in 1963 insisted to use Echinostoma for the generic name of this species and named it as E. malayanum, which was subsequently agreed by Mukherjee and Ghosh [18] and various other workers, even including Beaver et al. [19]. Since then, the name E. malayanum has been popularly used for a long time even until now by many workers around the world [20-23].

However, some workers preferred to use the name A. malayanum [24-27]. In particular, Kostadinova and Gibson [27] listed characteristic morphologies of this fluke, namely, the broadly oval and muscular body, very small head collar with faint ventral ridge, deeply branched testes, and long cirrus sac extending to the posterior margin of the ventral sucker, as the generic characteristics of Artyfechinostomum [16] and assigned it as A. malayanum. The present authors [9,11, present paper] followed Kostadinova and Gibson [27]'s suggestions admitting that these generic characteristics $[16,27]$ are significant. In addition, a molecular analysis of the mitochondrial cytochrome c oxidase subunit 1 (CO1) of A. malayanum in Thailand did not reveal any monophyletic clade with Echinostoma spp., including Echinostoma revolutum, but conformed to a different generic placement $[28,29]$. Therefore, we considered that it is more reasonable to include this fluke as a member of Artyfechinostomum rather than to assign it as Echinostoma.

There have also been debates on the synonymy of species within the genus Artyfechinostomum. After A. sufrartyfex Lane, 1915, the type species, was reported from a human infection in India [30], several additional species have been recorded. They included A. indicum (Bhalerao, 1931), A. malayanum (Leiper, 1911), A. mehrai (Faruqui, 1930), A. neotoma (Jain, 1953), A. palustris (Chatterii, 1932), and A. palustris rattus (Jain, 1953) [27]. Among them, synonymy was raised between $A$. malayanum and A. sufrartyfex, A. mehrai and A. sufrartyfex, and A. malayanum and A. indicum. Jain [31] and Ahluwalia [32] synonymized A. malayanum (as Euparyphium malayanum Odhner, 1913) with A. sufrartyfex; however, Lie [17] and Mukherjee and Ghosh [18] reversed it, by synonymizing A. sufrartyfex with Echinostoma malayanum. However, Premvati and Pande [24] acknowledged the genus Artyfechinostomum and synonymized A. sufrartyfex with A. malayanum. Kostadinova et al. [33] were of opinion that A. sufrartyfex is probably conspecific with A. malayanum. However, a molecular study on internal transcribed spacers (ITS1 and ITS2) of rDNA revealed that the synonymy between A. malayanum and A. sufrartyfex seemed not valid because there were 18 variable nucleotide positions out of 699 sequences examined; among them 17 could be used as diagnostic positions between these 2 sibling species [29]. With regard to A. mehrai, Ahluwalia [32] synonymized this species with A. sufrartyfex, which was agreed by Kostadinova et al. [33]. Premvati and Pande [24] synonymized A. mehrai with A. malayanum. However, the synonymy of A. mehrai with A. sufrartyfex or A. malayanum needs molecular confirmation in the future. The synonymy of A. indicum with A. malayanum [24] also needs molecular confirmation.

In conclusion, in this study, the metacercariae detected in Pila sp. snails from Phnom Penh, Cambodia were identified as those of A. malayanum Lane, 1915 based on morphological characteristics of the metacercariae and also of the adults recovered from experimentally infected laboratory animals using light and scanning electron microscopies. The present study confirmed for the first time the existence of the life cycle of $A$. malayanum in Cambodia.

\section{ACKNOWLEDGMENT}

We would like to thank the members of the Korea Association of Health Promotion who participated in the Korea-Cambodia international cooperative project on parasite control in schoolchildren in Cambodia (2008).

\section{CONFLICT OF INTEREST}

We have no conflict of interest related to this work.

\section{REFERENCES}

1. Leiper RT. A new echinostome parasite in man. J London School Trop Med 1911; 1: 27-28.

2. Bisseru B. On three known trematodes from African birds, with notes on the genera Typhlocoelum, Paryphostomum and Petasiger. J Helminthol 1957; 31: 173-186.

3. Bonne $\mathrm{C}$, Bras G, Lie KJ. Five echinostomes found in man in the Malayan Archipelago. Am J Digest Dis 1953; 20: 12-16.

4. Lie KJ. Studies on Echinostomatidae in Malaya. III. The adult Echinostoma malayanum Leiper, 1911 (Trematoda) and the probable synonymy of Artyfechinostomum sufrartyfex Lane, 1915. Z Parasitenkd 1963: 23: 124-135. 
5. Tangtrongchitr A, Monzon RB. Eating habits associated with Echinostoma malayanum infections in the Philippines. Southeast Asian J Trop Med Public Health 1991; 22 (suppl): 212-216.

6. Belizario VY, Geronilla GG, Anastacio MB, de Leon WU, Subaan AP, Sebastian AC, Bangs MJ. Echinostoma malayanum infection, the Philippines. Emerg Infect Dis 2007; 13: 1130-1131.

7. Maji AK, Bera DK, Manna B, Nandy A, Addy M, Bandyopadhyay AK. First record of human infection with Echinostoma malayanum. Trans R Soc Trop Med Hyg 1993; 87: 673.

8. Radomyos P, Radomyos B, Tungtronchitr A. Multi-infection with helminths in adults from northeast Thailand as determined by post-treatment fecal examination of adult worms. Trop Med Parasitol 1994; 45: 133-135.

9. Chai JY, Sohn WM, Yong TS, Eom KS, Min DY, Hoang EH, Phommasack B, Insisiengmay B, Rim HJ. Echinostome flukes recovered from humans in Khammouane Province, Lao PDR. Korean J Parasitol 2012; 50: 269-272.

10. Yu SH, Mott KE. Epidemiology and morbidity of food-borne intestinal trematode infections. Trop Dis Bull 1994; 91: R125R152.

11. Chai JY, Shin EH, Lee SH, Rim HJ. Foodborne intestinal flukes in Southeast Asia. Korean J Parasitol 2009; 47(suppl): S69-S102.

12. Sohn WM, Chai JY, Yong TS, Eom KS, Yoon CH, Sinuon M, Socheat D, Lee SH. Echinostoma revolutum infection in children, Pursat Province, Cambodia. Emerg Infect Dis 2011; 17: 117-119.

13. Sohn WM, Kim HJ, Yong TS, Eom KS, Jeong HG, Kim JK, Kang AR, Kim MR, Park JM, Ji SH, Sinuon M, Socheat D, Chai JY. Echinostoma ilocanum infection in Oddar Meanchey Province, Cambodia. Korean J Parasitol 2011; 49: 187-190.

14. Yong TS, Shin EH, Chai JY, Sohn WM, Eom KS, Lee DM, Park K, Jeoung HG, Hoang EH, Lee YH, Woo HJ, Lee JH, Kang SI, Cha JK, Lee KH, Yoon CH, Sinuon M, Socheat D. High prevalence of Opisthorchis viverrini infection in a riparian population in Takeo Province, Cambodia. Korean J Parasitol 2012; 50: 173-176.

15. Veciana M, Chaisiri K, Morand S, Ribas A. Helminths of the Asian house shrew Suncus murinus from Cambodia. Camdodian J Nat Hist 2012; 2: 115-122.

16. Odhner T. Ein zweites Echinostomum aus dem Menschen in Ostasien (Ech. malayanum Leiper). Zool Anz 41: 577-582.

17. Lie KJ. Studies on Echinostomatidae in Malaya. III. The adult Echinostoma malayanum Leiper, 1911 (Trematoda) and the probable synonymy of Artyfechinostomum sufrartyfex Lane, 1915. Z Parasitenkd 1963; 23: 124-135.

18. Mukherjee RP, Ghosh RK. On the synonymy of the genus Artyfechinostomum Lane, 1915 (Trematoda: Echinostomatidae). Proc Indian Acad Sci 1968; 67: 52-58.

19. Beaver PC, Jung RC, Cupp EW. Clinical Parasitology, 9th ed. Philadelphia, Pennsylvania, USA. Lea \& Febiger. 1984.

20. Maji AK, Bera DK, Manna B, Nandy A, Addy M, Bandyopadhyay
AK. First record of human infection with Echinostoma malayanum in India. Trans R Soc Trop Med Hyg 1993; 87: 673.

21. Belizario VY, Geronilla GG, Anastacio MB, de Leon WU, Subaan AP, Sebastian AC, Bangs MJ. Echinostoma malayanum infection, the Philippines. Emerg Infect Dis 2007; 13: 1130-1131.

22. Srisawangwong T, Sithithaworn P, Sukkasaen P, Jintakanon D, Tesana S, Sithithaworn J, Andrews RH, Fried B. Concomitant and protective immunity in mice exposed to repeated infections with Echinostoma malayanum. Exp Parasitol 2011; 127: 740-744.

23. Songsri J, Aukkanimart R, Boonmars T, Ratanasuwan P, Laummaunwai P, Sripan P. Animal models for Echinostoma malayanum infection: worm recovery and some pathology. Korean J Parasitol 2016; 54: 47-53.

24. Premvati G, Pande V. On Artyfechinostomum malayanum (Leiper, 1911) Mendheim, 1943 (Trematoda: Echinostomatidae) with synonymy of allied species and genera. Proc Helminthol Soc Wash 1974; 41: 151-160.

25. Eduardo SL. Artyfechinostomum malayanum (Leiper, 1911) Mendheim, 1943 (Trematoda: Echinostomatidae) from pigs in the Philippines. Phil J Vet Med 1989; 26: 25-27.

26. Roy B, Tandon V. Seasonal prevalence of some zoonotic trematode infections in cattle and pigs in the north-east montane zone in India. Vet Parasitol 1992; 41: 69-76.

27. Kostadinova A, Gibson DI. Isthmiophora Luhe, 1909 and Euparyphium Dietz, 1909 (Digenea: Echinostomatidae) re-defined, with comments on their nominal species. Syst Parasitol 2002; 52: 205-217.

28. Saijuntha W, Sithithaworn P, Duenngai K, Kiatsopit M. Andrews RH, Petney TN. Genetic variation and relationships of four species of medically important echinostomes (Trematoda: Echinostomatidae) in South-East Asia. Infect Gen Evol 2011; 11: 375381.

29. Tantrawatpan C, Saijuntha W, Sithithaworn P, Andrews RH, Petney TN. Genetic differentiation of Artyfechinostomum malayanum and A. sufrartyfex (Trematoda: Echinostomatidae) based on internal transcribed spacer sequences. Parasitol Res 2013; 112: 437441.

30. Lane C. Artyfechinostomum sufrartyfex, a new parasitic echinostome of man. Indian J Med Res 1915; 2: 977-983.

31. Jain GP. On the genus Artyfechinostomum (Lane, 1915) (Echinostomatidae: Trematoda). Parasitology 1960; 50: 1-5.

32. Ahluwalia SS. Studies on some helminths of the domestic pig (Sus scrofa domesticus) in Western Uttar Pradesh. J Helmonthol 1962; 36: 347-364.

33. Kostadinova A, Vaucher C, Gibson DI. Redescription of two echinostomes from birds in Paraguay, with comments on Drepanocephalus Diez, 1909 and Paryphostomum Dietz, 1909 (Digenea: Echinostomatidae). Syst Parasitol 2002; 53: 147-158. 
